\title{
IMPLEMENTASI PROGRAM PENGURANGAN SAMPAH DI KOTA BATAM TAHUN 2018
}

\author{
Muhammad Solihin ${ }^{1}$, Rahmayandi Mulda ${ }^{2}$ \\ ${ }^{1}$ Program Studi Ilmu Pemerintahan, Fakultas Ilmu Sosial dan Ilmu Politik, Universitas Riau Kepulauan, \\ Indonesia \\ sm10rome@gmail.com \\ ${ }^{2}$ Program Studi Ilmu Pemerintahan, Fakultas Ilmu Sosial dan Ilmu Politik,Universitas Riau Kepulauan, \\ Indonesia \\ rahmayandim@yahoo.co.id
}

\begin{abstract}
Abstrak
Pemilahan sampah tidak begitu masif dilakukan di Kota Batam. Sehingga memang dari sumber sampah kebanyakan sampah belum terpilah. Problem sampah di Kota Batam akan bertambah pelik jika tidak direncanakan dengan matang pengelolaanya khususnya dalam hal ini adalah pengurangan sampah. Tujuan khusus penelitian ini untuk mengetahui implementasi program pengurangan sampah di Kota Batam Tahun 2018 dan apa saja faktor yang mempengaruhi keberhasilannya. Tempat penelitian di kantor Dinas Lingkungan Hidup Kota Batam Bidang Pengelolaan Sampah dan lokasi Mitra pengurangan sampah. Jenis penelitian ini mengunakan pendekatan kualitatif dengan analisa deskriptif. Data yang dikumpulkan untuk penelitian wawancara, observasi dan dokumentasi. Teknik sample mengunakan purposive sampling. Hasil penelitian, Pertama: Indikator input belum ada Peraturan turunan dalam pengelolaan sampah rumah tangga di Kota Batam dan sumberdaya manusia dan organisasi unit pengeloaan bank sampah masih sangat minim. Kedua : Indikator output, tempat sampah di rumah-rumah (sumber sampah) masih terdiri dari satu jenis tempat sampah sehingga sampah memang tidak terpilah dari rumah. Adapun TPS3R dan Bank Sampah dinilai belum berjalan secara maksimal karena jumlah sangat sedikit sehingga pengurangan sampahnya juga tidak signifikan mengurangi sampah. Faktor yang mempengaruhi keberhasilan umumnya terkendala oleh minimnya sumberdaya apalagi bagi pegelola TPS3R dan Bank Sampah tidak memiliki instentif tetap dari pemerintah.

Kata Kunci: Manejemen Sampah, Program Pengurangan Sampah, Implementasi, Bank Sampah.
\end{abstract}

\begin{abstract}
Waste sorting is not so massive in Batam City. So indeed from the source of waste most of the waste has not been sorted. The problem of waste in the city of Batam will be complicated if it is not planned carefully, especially in this case is the reduction of waste. The specific purpose of this study was to determine the implementation of the waste reduction program in Batam City in 2018 and what factors influenced its success. Place of research in the office of Batam City Environment Agency for Waste Management and the location of waste reduction partners. This type of research uses a qualitative approach with descriptive analysis. Data collected for interview, observation and documentation research. The sample technique uses purposive sampling. The results of the study, First: There are no input indicators derived regulations in the management of household waste in the city of Batam and human resources and organization of waste bank management units are still very minimal. Second: The output indicator, the rubbish bin in the houses (the source of rubbish) still consists of one type of rubbish bin so that the rubbish is indeed not disaggregated from the house. The TPS3R and Waste Bank are considered not yet running optimally because the amount is very small so that the reduction of waste is also not significantly reduce waste. Factors that influence success are generally constrained by the lack of resources, especially for TPS3R managers and the Waste Bank does not have permanent incentives from the government.

Keywords: Garbage Management, Waste Reduction Program, Implementation, Garbage Bank.
\end{abstract}




\section{PENDAHULUAN}

Saat ini timbunan sampah di Indonesia per tahun masih tidak diolah dengan baik, menurut data dari Kementrian Lingkungan Hidup dan Kehutanan pada 2015 pada Gambar 1 di bawah ini:

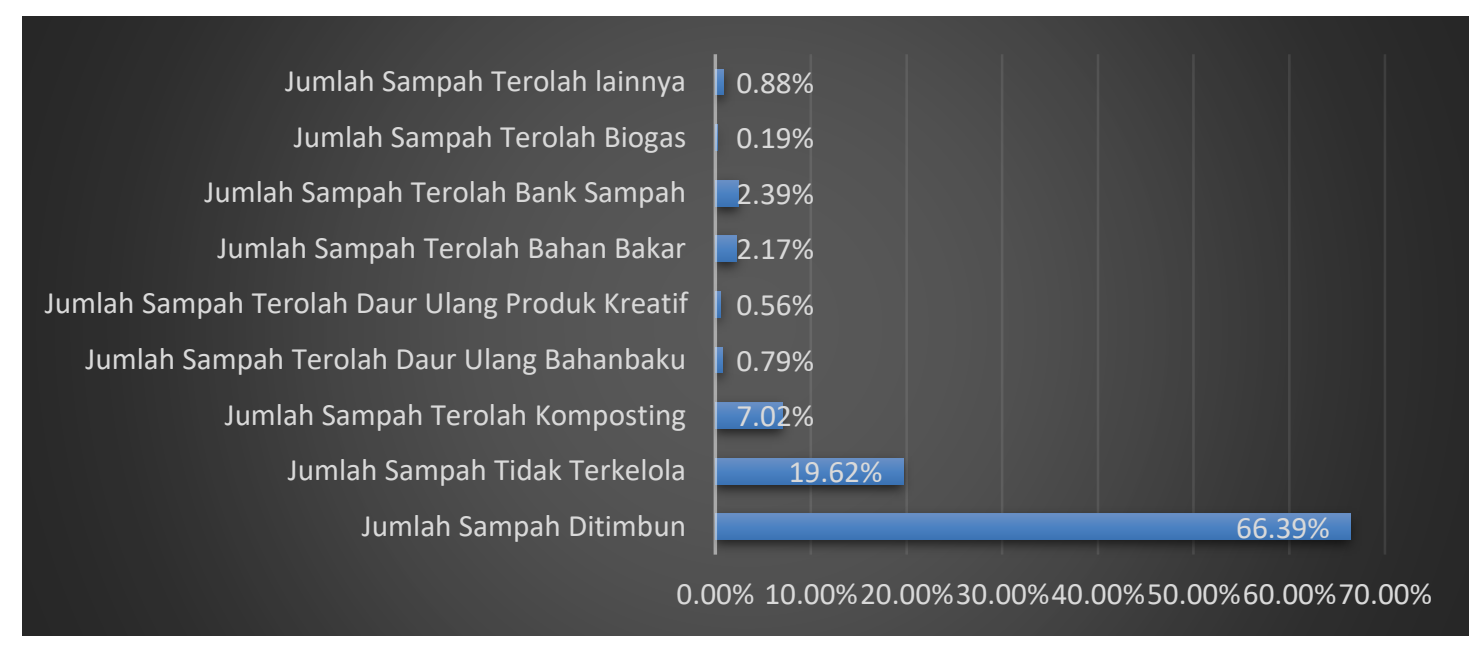

Gambar 1 Prosentase Pengelolaan Sampah Tahun 2015

Sumber: KLHK 2015

Pada Gambar 1 diatas tentang pengelolaan sampah di Indonesia 66,39 persen sampah ditimbun dan sampah tidak diolah sebanyak 19,62 persen. Hal ini berarti hanya 13.99 persen sampah yang diolah dan menjadi pengurangan sampah pertahun di Indonesia melalui bank sampah, biogas, bahan bakar, produk kreatif, bahan baku, composting dan lain-lain. Total ada sekitar 86.01 persen sampah belum terolah sama sekali di Indonesia hal ini tentu cukup mempritahatinkan apalagi mengingat pada Tahun 2025 Pemerintah telah menetapkan target dalam pengurangan sampah kantong plastik sebesar 30 persen sesuai dengan Perpres Nomor 97 Tahun 2017 tentang Kebijakan dan Strategi Nasional Pengelolaan Sampah Rumah Tangga dan Sampah Sejenis Rumah Tangga.

Pengelolaan sampah menjadi begitu vital dikarenakan salah satunya adalah sampah plastik yang memiliki dampak buruk bagi lingkungan: (1) Sampah palastik memerlukan waktu 1.000 tahun untuk bisa terurai secara sempurna; (2) Jika sampah plastik dibakar, terjadi proses pembakaran tidak sempurna yang menghasilkan gas beracun; dan (3) Para ilmuwan dari SCIRO (Commonwealth Scientific and Industiral Research Organization) dan Imperial College London mengatakan bahwa 90\% dari burung laut terdapat plastic di perutnya. Diperkirakan jumlah tersebut akan bertambah menjadi 99 persen pada tahun 2050 (Ekawati, 2016: 1). 
Pengurangan sampah sejatinya saat ini dipelopori oleh masyarakat dengan pengelolaan Bank Sampah di lingkungannya masing-masing. Saat ini jumlah Bank Sampah di Indonesia yang tersebar di 30 provinsi dan $206 \mathrm{Kab} / \mathrm{Kota}$.

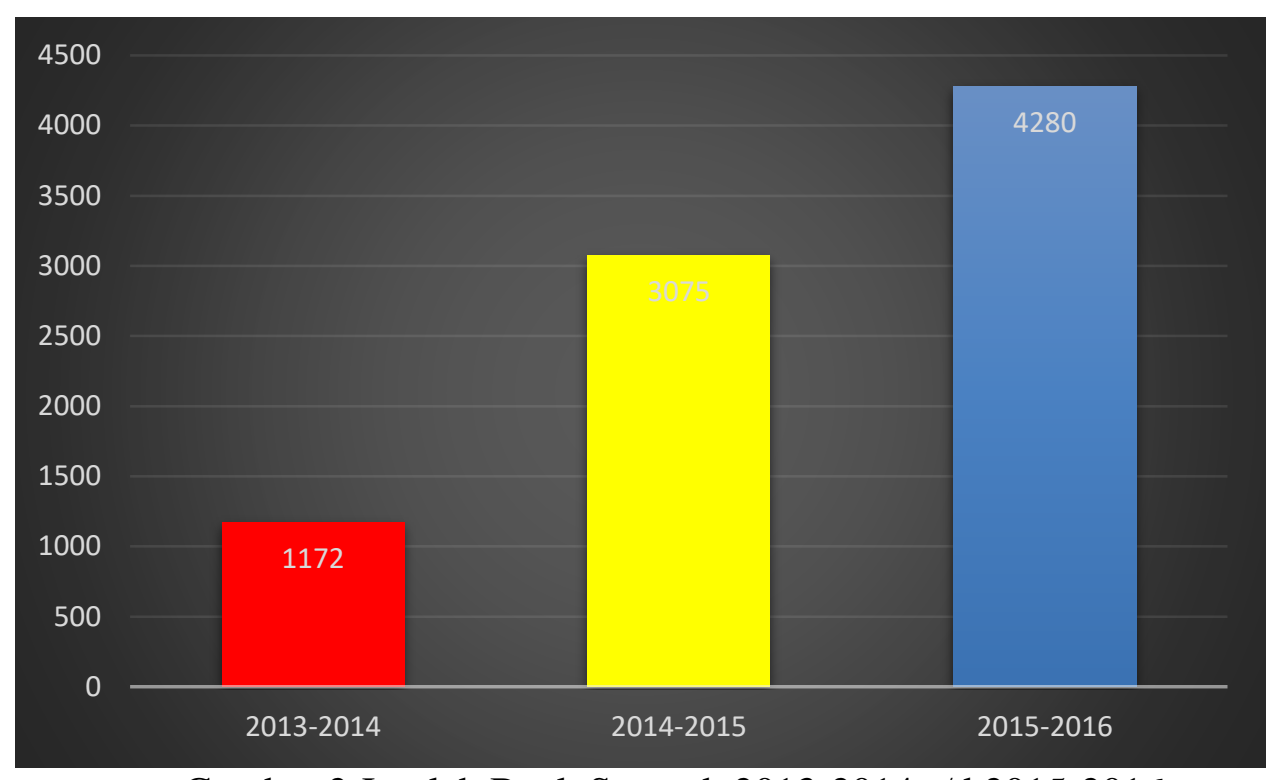

Gambar 2 Jumlah Bank Sampah 2013-2014 s/d 2015-2016

Sumber: KLHK 2015

Saat ini berdasarkan data dari KLHK jumlah Bank Sampah di Indonesia pada tahun 2015-2016 sebanyak 4280 di seluruh Indonesia. Namun walaupun meningkat dari tahun sebelumnya, jumlah ini tentu tidak terlalu berpengaruh signifikan jika membandingkan tonase sampah pada tahun 2013 sebanyak 817.026,68 ton/tahun, meningkat pada tahun 2014 sebanyak 1.096.905,71 ton/tahun, dan 2015 sebanyak 1.099.188,47 ton/tahun.

Permasalahan di Provinsi Kepulauan Riau khususnya Kota Batam Saat ini juga menjadi permasalahan penting untuk menjadi prioritas mengingat jumlah penduduk kota Batam per 2015 berjumlah 1.020.529 jiwa yang bisa disebut dalam karakteristik Kota Metropolitan. Diperkirakan penduduk akan tumbuh sekitar 2,8 Juta jiwa pada tahun 2037. Tentu dengan estimasi peningkatan penduduk tersebut kota Batam tentu tak luput dari masalah-masalah sosial seperti kota-kota besar lainnya di Indonesia. Salah satu masalah yang dihadapi adalah permasalahn sampah. Seiring dengan meningkatnya jumlah populasi di kota Batam tentu juga akan diiringi peningkatkan jumlah sampah dari konsumsi rumah tangga, industri dan lain-lain. 
Tabel 1 Tonase Sampah Kota Batam Tahun 2016 - 2017

\begin{tabular}{|l|c|c|}
\hline \multicolumn{1}{|c|}{ Tahun } & $\mathbf{2 0 1 6}$ & $\mathbf{2 0 1 7}$ \\
\hline Sampah & 298.218 .953 ton/Tahun & 283.476 .610 ton/Tahun \\
\hline
\end{tabular}

Pada tabel 1 diatas sampah pada tahun 2016 sebanyak 298.218.953 ton/tahun dan pada tahun 2017 sebanyak 283.476.610 ton/tahun. Pada tahun 2017 tonase sampah perhari telah mencapai 776.648 ton/hari (Solihin dan Parlindungan, 2018: 84). Jika tidak dilakukan pengurangan sampah dengan 3R (Reduce, Reuse, Recycle) dari sumber tentu permasalahan sampah ini akan menjadi masasalah yang tak kunjung selesai.

Terpilahnya jenis sampah saat ini dalam pangangkutan sampah belum dilakukan oleh pihak pemerintah secara maksimal. Berdasarkan keterangan dari Ibu Rida Meliyana S.E, Selaku Kepala Seksi Pengurangan Sampah DLH Kota Batam.

"untuk pengurangan sampah sendiri kita mengalakan proses pemilahan sampah berbasis masyarakat dengan cara memisahkan sampah dari sumbernya. Saat ini terdapat sebanyak 260 Bank Sampah yang tersebar di 10 Kecamatan di Kota Batam"

Dari Keterangan Ibu Rida saat ini Bank Sampah di Kota Batam terdapat sebanyak 260 Bank Sampah yang tersebar di 10 Kecamatan di Kota Batam dengan pengurangan sampah yang tergolong kecil yakni hanya 30 ton/pertahun pada Tahun 2017.

Dalam hal pemilahan sampah sendiri tidak begitu masif terjadi dikarenakan tempat sampah di rumah-rumah (sumber sampah) masih terdiri dari satu jenis tempat sampah saja. Sehingga memang dari sumber sampah kebanyakan sampah memang belum terpilah. Padahal sejatinya sampah bisa diolah menjadi bahan bakar, energi, kompos, dan lain-lain.

Problem sampah di Kota Batam akan bertambah pelik jika tidak direncanakan dengan matang pengelolaanya khususnya dalam hal ini adalah pengurangan sampah. Dalam penelitian ini peneliti akan melihat implementasi program pengurangan sampah di Kota Batam tahun 2018 yang dilaksanakan oleh Dinas Lingkungan Hidup Bidang Pengelolaan Sampah Kota Batam.

\section{METODELOGI}

Penelitian ini dilaksanakan pada bulan Mei - September 2019. Tempat penelitian di sekretariat Dinas Lingkungan Hidup Kota Batam Bidang Pengelolaan Sampah. Tempat lain di lokasi Mitra pengurangan sampah. Jenis penelitian ini mengunakan pendekatan kualitatif dengan analisa deskriptif. Metode deskriftif diartikan sebagai prosedur pemecahan, masalah yang diselidiki dengan mengambarkan objek yang diteliti, seperti idividu, lembaga, 
masyarakat dan lain-lain, pada saat sekarang berdasarkan fakta-fakta yang tampak atau sebagaimana adanya (Nawawi, 1992: 63). Bogdan \& Taylor dalam Moleong (2007: 4) mendefinisikan metode kualitatif sebagai prosedur penelitian yang menghasilkan data deskriptif berupa katakata tertulis atau lisan dari orang-orang dan perilaku yang dapat diamati. Data yang dikumpulkan untuk penelitian ini berupa data primer dan data sekunder. Adapun sumber data tersebut, yaitu : Data primer dikumpulkan secara langsung dilapangan dari responden dengan wawancara dan observasi lapangan di lingkungan Dinas Lingkungan Hidup Kota Batam dan Mitra pengurangan Sampah. Data Sekunder didapat dari studi kepustakaan dari dokumen-dokumen Dinas Lingkungan Hidup Kota Batam, Mitra Pengurangan Sampah, kecamatan, media massa, media elektronik, serta sumber-sumber tertulis lainnya. Pengumpulan data dalam penelitian ini mengunakan teknik purposive sampling. Teknik ini digunakan untuk memperoleh informan dala organisasi atau kelompok yang terbatas untuk menemukan informan yang tepat. Adapun sumber data peneliti adalah: Kepala Seksi Pengurangan Sampah, Kelompok Bank Sampah Allium Kecamatan Sagulung, Kelompok Bank Sampah Rindang Kecamatan Batu Aji, Unit Bank Sampah Paradise, Unit Bank Sampah Puskopkar, dan masyarakat. Analisis data dalam penelitian ini menggunakan Model Interaktif menurut Miles dan Hubberman dalam Sugiyono (2011: 224). Analisis model interaktif tersebut, terdiri dari pengumpulan data, reduksi data, penyajian data, dan penarikan kesimpulan.

\section{PEMBAHASAN}

Menurut Purwanto dan Sulistyastuti (2012: 21) implementasi adalah kegiatan untuk mendistribusikan keluaran kebijakan (to delivery policy output) yang dilakukan oleh para implementer kepada kelompok sasaran (target group) sebagai upaya untuk menwujudkan tujuan kebijakan. Tujuan kebijakan diharapkan akan muncul manakala policy output dapat diterima dam dimanfaatkan dengan baik oleh kelompok sasaran sehingga dalam jangka panjang hasil kebijakan akan mampu diwujudkan. Penulis akan melakukan pembahasan dari dua indikator implementasi kebijakan. Implementasi program di lapangan yang dimana akan dinilai dari (1) Indikator masukan kebijakan (policy input); (2) Indikator Keluaran Kebijakan (policy output). Berikut analisis penulis mengenai 2 indikator tersebut dalam penelitian ini.

\section{Indikator Masukan Kebijakan}

1. Peraturan Daerah 
a. Peraturan Daerah Kota Batam No 11 Tahun 2013 tentang Pengelolaan Sampah

Peraturan Daerah yang mengatur adalah Peraturan Kota Batam No 11 Tahun 2013 Tentang Pengelolaan Sampah. Pada peraturan ini Pengelolaan Sampah terdiri dari (1) Pemilahan sampah; (2) Pengumpulan sampah; (3) Pengangkutan sampah; (4) Pengolahan sampah; dan (5) Pemprosesan akhir sampah. Dalam penelitian ini penulis membatasi pada persoalan pengangkutan sampah.

Pada peraturan daerah ini harusnya sudah ada pemilahan sampah sejak dirumah tangga dengan menerapkan tiga jenis tempat sampah. Namun pelakasanaan dimasyarakat tidak terlaksana dikarenakan masyarakat umumnya hanya memiliki satu tempat sampah aja. Tidak ada sangsi yang jelas dalam penerapan Peraturan Deaerah ini.

b. Peraturan Presiden No 97 Tahun 2017 tentang Kebijakan dan Strategi Nasional Pengelolaan Sampah Rumah Tangga dan Sampah Sejenis Sampah Rumah Tangga

Pada Peraturan Presiden ini mengatur peran serta pemerintahan tingkat kementerian, Pemerintah Provinsi, Pemerintah Kota untuk membuatkan peraturan turunan, melakukan penganggaran untuk kegiatan penguran sampah Sampah Rumah Tangga dan Sampah Sejenis Rumah Tangga. Namun saat ini menurut Ibu Rida Meliyanan S.E, Selaku Kepala Seksi Pengurangan Sampah DLH Kota Batam peraturan turunan dari Perpres tersebut belum ada.

"untuk pengurangan sampah sebenarnya Pemerintah Pusat sudah mengatur ya, yakni pengurangan sampah sebanyak $30 \%$ pada tahun 2025 pada perpres no 97 Tahun 2017, namun susahnya memang peraturan pengurangan sampah itu belum memiliki peraturan turunan di tingkat daerah (pemerintah Kota Batam)." (20 Mei 2019)

Target pengurangan sampah yang diamanatkan Perpres ini dalam pasal 2 ayat (1) huruf b, yakni (1) pengurangan Sampah Rumah Tangga dan Sampah Sejenis Rumah Tangga sebesar 30\% (tiga puluh persen) dari angka timbulan Sampah Rumah Tangga dan Sampah Sejenis Rumah Tangga di tahun 2025. (2) Penanganan Sampah Rumah Tangga dan Sampah Sejenis Rumah Tangga sebesar 70\% dari angka timbulan sampah

2. Organisasi Pelaksana

Dalam pengurangan sampah organisasi pelaksana dalam hal ini ada 3 pihak, yakni: Pertama, Dinas Lingkungan Hidup sub bagian Pengurangan Sampah antara lain memiliki fungsi sebagai berikut: 1) Penyusunan program dan rencana kerja lingkup Pengurangan 
Sampah, 2) Penyusunan petunjuk teknis operasional lingkup Pengurangan Sampah, 3) Pelaksanaan pengendalian lingkup Pengurangan Sampah, dan, 4) Pelaksanaan, monitoring, evaluasi dan pelaporan pelaksanaan lingkup Pengurangan Sampah. Kedua, Unit Bank Sampah merupakan mitra DLH dalam melakukan program pengurangan sampah. Unit Bank sampah bertugas mengelola sampah organik dan sampah anorganik. Sampah organik diolah menjadi Pupuk, Eco Ensyim, Biovori dimana setelahnya akan dimanfaatkan untuk melakukan penanaman bibit seperti sayur dan buah-buahan. Hasilnya ada juga yang di jual. Untuk sampah anorganik unit Bank Sampah dengan nasabah Bank Sampah melakukan pengurangan sampah dengan pemilahan sampah anorganik yang bernilai ekonomis. Ketiga, Nasahan Bank Sampah adalah warga binaan unit Bank Sampah yang melakukan pemilihan sampah rumah tangga. Setiap waktu yang ditentukan masyarakat ini akan memberikan sampah anorganik kepada unit Bank Sampah. Keempat, Tempat Pengelolaan Sampah (TPS) Reduce, Recycle, Reuse (3R) TPS 3R mempunyai fungsi untuk melakukan pengurangan sampah, pengelolaan sampah organik dan anorganik menjadi produk-produk terntentu sehingga bisa digunakan kembali.

3. Sumber Daya

Adapun sumberdaya manusia yang ada di Dinas Lingkungan Hidup Kota Batam divisi pengurangan sampah terdiri dari 1 Kepala Seksi, 2 Staff dan 15 Pengolah Sampah 3R. sedangkan fasilitas untuk pengurangan sampah 1 lori, 1 pick up, 2 kendaraan roda tiga. Transportasi inilah yang digunakan untuk mengangkut sampah nonorganik yang bernilai ekonomis di Unit Bank Sampah dengan jadwal masing-masing ditentukan oleh Unit Bank Sampah sesuai dengan kapasitas. Penjadwalan dilakukan dikarenakan terbatasnya fasilitas angkutan dari DLH Kota Batam.

Selain tenaga dari Dinas Lingkungan Hidup Kota Batam. Pengurangan sampah dibantu oleh Unit Bank Sampah yang pada tahun 2018 terbentuk sebanyak 203 Unit Bank Sampah dan 2 unit TPS3R yang merupakan tenaga yang bersifat sosial. Tidak ada insentif untuk Unit Bank Sampah tersebut setiap bulannya. Kendalanya tidak ada sangksi mengikat jika ada unit bank sampah atau TPS3R yang tidak berjalan optimal. 


\section{Indikator Keluaran Kebijakan}

1. Akses

Adapun akses pengurangan sampah sesuai dengan Perda No 11 Tahun 2013 Pertama, pemerintah harus membentuk Unit Bank Sampah dan memberikan Pelatihan dalam Pengurangan dan Pengelolaan Sampah, Kedua, Unit Bank Sampah melakukan sosialiasi dan pelatihan kepada masyarakat untuk memisahkan sampah organic yang bisa diolah, dan sampah anorganik yang dijual untuk bisa di rcyle kembali oleh perusahaan. Ketiga, Nasabah Bank Sampah menngirimkan sampah yang bernilai ekonomi pada jadwal yg sudah ditentukan. Lalu Bank sampah dengan bantuan transportasi dari Dinas Lingkungan Hidup menjual kepada pihak perusahaan pembeli sampah ekonomis tersebut. Keempat, Hasil dari penjualan sampah bernilai ekonomi akan diberikan kepada nasabah Bank Sampah setelah dipotong 15\% untuk pengelolah unit Bank Sampah.

Indikator akses digunakan untuk mengetahui seberapa mudah program atau pelayanan yang diberikan dapat dijangkau oleh kelompok sasaran. Selain itu juga akses mengandung pengertian bahwa seberapa mudah kelompok sasaran menjangkau para pelekasana implementasi untuk mengetahui informasi mengenai program serta menyampaikan pengaduan jika mendapatkan permasalahan selama proses implementasi program kebijakan. Selain itu indikator akses juga menilai apakah ada diskriminasi terhadap kelompok sasaran terkait program yang mereka terima.

Akses pengurangan sampah di Kota Batam menurut $\mathrm{Bu}$ Rida yakni dengan mengalakkan pembetukan Unit Bank Sampah di setiap kelurahan. Selain unit Bank Sampah juga ada Tempat Pengelolaan Sampah 3R. Akses pengurangan sampah dilakukan oleh berbagai macam aktor yakni:

a. Rumah Tangga

Sesuai Peraturan Daerah Kota Batam No 11 Tahun 2013 tentang Pengelolaan Sampah setiap rumah tangga harusnya menyediahkan 3 jenis tempat sampah. Pertama, Tempat sampah organik, Kedua, Tempat sampah anorganik, dan Ketiga, Tempat sampah B3.

Pada Peraturan tersebut pada Pasal 6 ayat (1) Setiap orang/atau badan harus menyediahkan wadah sampah untuk menampung sampah sementara. Namun di Kota Batam sebagian besar masyarakat hanya mengunakan satu jenis Tempat sampah. 1 jenis tempat sampah itu masyarakat membuang semua jenis limbah 
rumah tangga dari plastik, sayuran, streofoam, sampah kaca, baterai dan lain-lain. Arson Andreas (54)warga Keluarahan Tanjung Sengkuang Perumahan Bukit Makmur mengatakan bahwa di depan rumah hanya mempunyai 1 jenis tempat sampah yang selanjutnya setiap jenis sampah dimasukan ke satu jenis tempat sampah itu tanpa dipilah. Hal ini melingkupi perumahan Bukit Makmur yang semua warga hanya memiliki 1 jenis tempat sampah untuk membuang semua jenis sampah.

"Di depan rumah itu sudah disediakan tong sampah, tepatnya 1 jenis kota sampah. Jadi semua jenis sampah dimasukan ke satu tong yang sama seperti plastik, baterai, bolam semua masuk" (17 Juni 2019)

Warga Batu Aji yakni Jhon Peris Surbakti (49) Muka Kuning Paradise, Bukit Tempayan, mengatakan di tempat tinggalnya masyarkat rata-rata hanya memiliki 1 jenis tong sampah.

"Saya membuang sampah di depan rumah, kalo kita hanya 1 tong sampah aja, jadi semua sampah masuk semua jenis di tong itu. Seluruh perumahan kami seperti itu, seluruh perumahan di Kota Batam rata-rata juga seperti itu. Namun untuk sampah yang bernilai ekonomis di perumahan kami ada pemilihan untuk di salurkan ke Bank Sampah" (20 Juni 2019)

Namun pemilahan sampah di Perumahan Paradise dilakukan oleh unit Bank Sampah Paradise 1 bulan sekali. Sampah dikumpulkan 1 bulan sekali untuk lagsung diangkut oleh DLH Kota Batam seperti terlihat pada gambar dibawah ini.

Nina Jemita Sari (30) Perumahan Baloi Center, Batam Center mengatakan pemilahan sampah tidak terjadi dikarenakan Unit Bank Sampah di perumahaanya tidak lagi aktif. Namun dulu ada aktifitas pengurangan sampah yang dipelopori oleh unit Bank Sampah. Saat ini sampah plastik, kardus, kaca, dan limbah rumah tangga dibuang pada satu tempat sampah.

"saya buang sampah biasanya ke TPS, untuk jenis tempat sampah diperumahan kami rata-rata dijadikan satu semua, semua jenis kami masukan pada satu tempat plastic, kardus, kaca jadi satu semuanya. Untuk saat ini ditempat kami tidak ada pemilahan sampah di rumah tangga, dulu ada Bank Sampah namun dikarenakan pengurusnya pindah akhirnya tidak aktif lagi. Dulu si ada pengumpulan plastic dan kardus gitu." ( 27 Juni 2019)

Elvi Zahendra (32) Kavling Cendrawasih, Tiban Pajak, Patam Lestari Sekupang menyatakan aktivitas pembuangan sampah di daerahnya tidak lagi 
mengunakan tong sampah, namun saat ini sudah digantung di tiang yang dibuat sendiri. Tiang ini atas hasil kesepakatan perangkat di lingkungan setempat. Sampah berjenis plastic, kardu dan lain-lain mereka buang dalam satu kantong plastik yang kemudian akan diangkut oleh armada pengangkutan sampah DLH Kota Batam.

"Kami sampah itu digantung pak, nanti mobil sampah ngambil. Kami ga ada tong sampah karena sudah ada gantungan itu. Semua jenis sampah kami masukan seperti plastik, kardus dan lain-lain" (27 Juni 2019)

Putri Meilani (35) Kavling Bengkong Kolam, Bengkong menyatakan mereka juga masih membuang sampah pada 1 jenis tempat saja. Mereka masih memasukan sampah seperti botol bekas, sayur, dan sampah lainnya pada satu jenis tempat sampah saja.

"Saya buang sampah di tong sampah, di depan rumah, warna biru. Di lingkungan disini biasanya rata-rata satu jenis tong sampah saja. Jadi semua jenis sampah dimasukan kesana misalnya botol bekas, sayur dan lain-lain. Di lingkungan kami tidak ada pemilahan sampah" (30 Juni 2019)

Sella Ramadhani (29) Kavling Kamboja, Dapur 12, Kecamatan Sagulung menyatakan di kavling perumahannya warga mayoritas masih mengunakan satu jenis tempat sampah dan membuang sampah semua jenis pada tempat sampah yang sama.

"saya buang sampah ke tong sampah depan rumah. Jenis tong sampah saya cuma satu yaitu tong sampah drum warna biru, jadi semua jenis sampah digabung jadi satu seperti sampah rumah tangga, plastik, sampah hewan peliharaan" (19 Juni 2019)

Pada Masyarakat pada umumnya di beberapa Kecamatan di Kota Batam masih banyak masyarakat yang belum melakukan pemilahan sejak di rumah tangga. Sehingga proses pengunrangan sampah di Kota Batam masih sangat kecil. Dari beberapa warga yang diwawancarai mereka memang mengaku belum perna menerima sosialisasi tentang program tersebut.

b. Unit Bank Sampah

Pengurangan sampah selanjutnya dilakukan oleh unit Bank Sampah yang dibentuk oleh Dinas Lingkungan Hidup Kota Batam. Saat ini sudah ada 203 unit Bank Sampah yang tersebar di Kota Batam. 
Adapun alur pengurangan sampah anorganik adalah sebagai berikut:

1) Nasabah Bank Sampah menyetor Sampah anorganik yang bernilai ekonomis;

2) Unit Bank Sampah menerima sampah anorganik yang bernilai ekonomis, lalu 1 bulan sekali sampah tersebut di angkut oleh Dinas Lingkungan Hidup;

3) Dinas Lingkungan Hidup mengatarkan sampah tersebut ke pabrik, selanutnya DLH menerima pembayaran. Lalu pembayaran tersebut langsung DLH transfer dananya langsung ke unit Bank Sampah dengan tidak memungut biaya apapun;

4) Unit Bank Sampah melakukan distribusi dana tersebut ke Nasabah Bank dengan terlebih dahulu menyisikan 10persen untuk operasional Bank Sampah.

Dewi Mariana (36) Unit Bank Sampah Allium, Kelurahan Sei Langkai, Kecamatan Sagulung menceritakan bahwa pemilahan sampah dilakukan oleh nasabah Bank Sampah seperti kardus, plastik dan sampah anorganik lain yang bernilai ekonomis untuk direcylce di pabrik.

Program kami di allium, kami menerima sampah ekonomis baik yang kotor dan bersih dari nasabah Bank Sampah kami, lalu sebulan sekali pada minggu pertama kami melakukan penimbangan, selanjutnya sampah bernilai ekonomis tersebut diangkut oleh DLH Kota Batam untuk dijual ke pabrik. (23 Juli 2019)

Sampah anorganik yang tidak bernilai ekonomis juga dimanfaatkan Unit Bank sampah untuk dibuat kerajinan tangan berupa Tas, Dompet, dan lain-lain. Selain itu pengurangan sampah lainnya yang dilakukan oleh Unit Bank Sampah adalah pengolahan sampah anorganik yang tidak mempunyai nilai ekonomis seperti plastik sachet dari kopi menjadi tas, dompet, dan tempat tisu dan lain-lain.

Untuk pengurangan sampah organik, Unit Bank Sampah umumnya menjadikan sampah seperti daun, sampah rumah tangga menjadi pupuk, ekoenszim, dan biovori.

c. TPS 3R

Tempat pengeleloaan Sampah Reduce, Recycle dan Reuse. Program TPS 3R di Tiban Lama melakukan pengolahan sampah organik menjadi pupuk cair dan pupuk. Sampah anorganik TPS 3R juga melakukan penjualan sampah kardus 
dan plastik seperti juga yang dilakukan oleh Unit Bank Sampah. TPS 3R Tiban Lama juga memiliki tempat melakukan pembibitan tanaman di wilayahnya.

Adapun pembibitan di TPS 3R ini mempunyai produk bibit seperti bibit petai, jengkol, mahoni, dan lain-lain. Kedepannya bibit ini akan ditanami di hutan Tiban Lama agar tidak gundul namun juga bernilai ekonomis bagi warga sekitar.

\section{Frekuensi}

Indikator ini mengukur seberapa sering kelompok sasaran mendapatkan layanan bantuan yang dijanjikan oleh program kebijakan. Semakin tinggi tingkat frekuensi layanan maka semakin baik implementasi program kebijakan itu sendiri terutama program-program yang layanannya tidak diberikan hanya sekali tapi berulang kali.Frekuensi pengurangan sampah yang dapat dihitung ialah melalui pengurangan sampah yang berada di unit Bank Sampah dan TPS 3R.

a. Unit Bank Sampah

Berdasarkan keterangan Dewi Mariana (36) Unit Bank Sampah Allium , Sei Langkai, Sagulung. Penjemputan sampah anorganik yang bernilai dilakukan oleh Dinas Lingkungan Hidup 1 bulan sekali untuk kapasitas 500 kg. kapasitas 200 kg biasanya 3 bulan sekali.

"Penimbangan total ditempat kami itu dilakukan tiap awal bulan 1 bulan sekali, biasanya dihari sabtu dan minggu. Untuk sampah yang dikurangi kadang $500 \mathrm{~kg}$ dan paling maksimum itu 1000 kg.Pengurangan sampah yang lain kami lakukan dengan membuat pupuk kompos, biovori, ecoenzim." (2019)

Tabel 2 Jenis Sampah Anorganik Yang Bernilai Ekonomis

\begin{tabular}{|l|l|}
\hline No & Jenis Sampah \\
\hline 1 & Aqua Gelas Bersih \\
\hline 2 & Aqua Gelas Kotor \\
\hline 3 & Botol Plastik Bersih \\
\hline 4 & Botol Plastik Kotor \\
\hline 5 & Tee Gelas / Monti / Pipet \\
\hline 6 & Ember \\
\hline 7 & Tutup Galon \\
\hline 8 & Tutup Botol \\
\hline 9 & Asoi \\
\hline 10 & Ember Hitam \\
\hline 11 & Aki Bekas \\
\hline 12 & Kaset CD \\
\hline 13 & HDPE \\
\hline 14 & Kaleng Alka (Alumunium) \\
\hline 15 & Kaleng Susu (Mengandung Besi) \\
\hline 16 & ALMa \\
\hline 17 & Karton (Kardus) \\
\hline
\end{tabular}




\section{b. TPS 3R}

\begin{tabular}{|l|l|}
\hline 18 & Buku Paket Pelajaran \\
\hline 19 & HVS (Kertas Putih) \\
\hline 20 & Kertas Padat \\
\hline 21 & Koran Bekas \\
\hline
\end{tabular}

Sumber: DLH Kota Batam, 2019

Frekuensi pengurangan sampah di TPS 3R Tiban Lama tidak terlalu massif dikarenakan sampah tidak banyak terkumpul oleh nasabah bank sampah. Jadwal penimbangan sampah di TPS 3R di Tiban lama dilakukan 3 bulan sekali. Sebanyak $200 \mathrm{~kg}$.

3. Cakupan

Indikator ini digunakan untuk menilai berapa besar kelompok sasaran yang dapat dijangkau oleh kebijakan yang diimplementasikan. Pengurangan sampah di Kota Batam yang dilaksanakan oleh Unit Bank Sampah yang dibentuk oleh Dinas Lingkungan Hidup Kota Batam bagian pengurangan sampah. Cakupan Unit Bank Sampah di Kota Batam pada Tahun 2018 sudah tersebar di 12 kecamatan.

Tabel 3 Jumlah Bank Sampah di Kota Batam Tahun 2018

\begin{tabular}{|l|l|l|}
\hline No & Kecamatan & Jumlah \\
\hline 1 & Sagulung & 47 \\
\hline 2 & Batu Aji & 45 \\
\hline 3 & Sekupang & 19 \\
\hline 4 & Lubuk Baja & 10 \\
\hline 5 & Batam Kota & 28 \\
\hline 6 & Batu Ampar & 15 \\
\hline 7 & Bengkong & 18 \\
\hline 8 & Sei Beduk & 17 \\
\hline 9 & Nongsa & 1 \\
\hline 10 & Bulang & 2 \\
\hline 11 & Galang & 0 \\
\hline 12 & Belakang Padang & 1 \\
\hline Jumlah & 203 \\
\hline
\end{tabular}

Sumber: DLH Kota Batam, 2019

Walaupun saat ini sudah ada unit Bank Sampah namun masih banyak Bank Sampah yang masih belum optimal kinerjanya. Seperti ada yang mati suri, kegiatan pengurangan sampah dilakukan 3 bulan sekali. Untuk jumlah pengurangan sampah sendiri masih sangat jauh dari harapan pemerintah pusat yakni mengurangi timbunan sampah sebanyak 30\% dari timbunan sampah rumah tangga. Dari Tabel dibawah ini setiap bulannya Kota Batam hanya menguragi sampah sebanyak 20,3 ton/bulan. Sedangkan timbunan sampah perhari Kota Batam Tahun 2018 adalah sebanyak 900 
Ton/Hari. Jelas jika melihat gap tersebut jumlah Bank Sampah dengan jumlah timbulan sampah sangat tidak seimbang. Diperlukan gerakan pemilahan sampah sejak dari rumah tangga (sumber sampah).

Tabel 4 Jumlah Pengurangan Sampah di Kota Batam Tahun 2018/Bulan

\begin{tabular}{|l|c|c|}
\hline No & Kecamatan & $\begin{array}{c}\text { Pegurangan Sampah } \\
\text { Kg/Bulan }\end{array}$ \\
\hline 1 & Sagulung & $4700 \mathrm{~kg}$ \\
\hline 2 & Batu Aji & $4500 \mathrm{~kg}$ \\
\hline 3 & Sekupang & $1900 \mathrm{~kg}$ \\
\hline 4 & Lubuk Baja & $1000 \mathrm{~kg}$ \\
\hline 5 & Batam Kota & $2800 \mathrm{~kg}$ \\
\hline 6 & Batu Ampar & $1500 \mathrm{~kg}$ \\
\hline 7 & Bengkong & $1800 \mathrm{~kg}$ \\
\hline 8 & Sei Beduk & $1700 \mathrm{~kg}$ \\
\hline 9 & Nongsa & $100 \mathrm{~kg}$ \\
\hline 10 & Bulang & $200 \mathrm{~kg}$ \\
\hline 11 & Galang & 0 \\
\hline 12 & Belakang Padang & $100 \mathrm{~kg}$ \\
\hline & Jumlah & $20.300 \mathrm{~kg} /$ Bulan \\
\hline
\end{tabular}

Sumber: DLH Kota Batam

Selain unit Bank Sampah, pengurangan sampah juga dilakukan oleh Pemerintah Kota Batam melalui TPS 3R yang berjumlah 2 di Kota Batam yakni TPS 3R Tiban Lama dan TPS 3R Tanjung Sengkuang.

4. Bias

a. Tidak adanya peraturan turunan

Pada Peraturan Presiden ini mengatur peran serta pemerintahan tingkat kementerian, Pemerintah Provinsi, Pemerintah Kota untuk membuatkan peraturan turunan, melakukan penganggaran untuk kegiatan penguran sampah Sampah Rumah Tangga dan Sampah Sejenis Rumah Tangga. Namun saat ini menurut Ibu Rida Meliyanan S.E, Selaku Kepala Seksi Pengurangan Sampah DLH Kota Batam peraturan turunan dari Perpres tersebut belum ada.

b. Pemilahan sampah tidak didukung fasilitas

Sejatinya pemilihan sampah harusnya dilakukan sejak di sumber sampah yakni rumah tangga dengan tersedianya 3 jenis tempat sampah yakni organik, anorganik dan B3. Selain itu armada pengangkutan sampah juga harus mengangkut sampah sesuai dengan jenisnya masing-masing. Namun hal tersebut tidak terjadi dikarenakan fasilitas yang tidak tersedia.

c. Minimnya Sosialiasasi 
Minimnya Sosialisasi dan komunikasi kepada masyarakat mengakibatkan kebijakan pemerintah tentang pengurangan sampah di Kota Batam tidak berjalan secara efektif, selain itu, hal lain menimbulkan kebijakan menjadi bias karena dukungan pendanaan dari pemerintah daerah terhadap aturan atau kebijakan sangat minim sehingga aparat atau tenaga teknis dilapangan terhambat dalam menjalangkan berbagai program menganai kebijakan pengurangan sampah. Dari hasil observasi dilapangan umumnya masyarakat yang terlibat dalam kelompok bank sampah merupakan relawan yang dibina oleh Dinas yang terkait yakni Dinas Lingkungan Hidup Kota Batam dan hal tersebut mereka bekerja secara sukarela karena kesadaran terhadap kebersihan lingkungan.

5. Ketepatan Layanan

Dalam melihat ketepatan layanan dalam hal ini kebijakan tentang pengurangan sampah dinilai masih sangat kurang namun kebijakan ini sangat tepat untuk dilakukan kedepannya, mengingat hal ini merupakan kebijakan yang langsung berdampak ke masyarakat Untuk ketepatan layanan menurut Bapak Arson Andreas (44) Tanjung Sengkuang Perumahan Bukit Makmur menjelaskan pengurangan sampah di wilayahnya untuk terus dilakukan karena permaslahan sampah ini adalah permasalahan keseharian yang harus di selesaikan setiap harinya..

"Harusnya pemerintah lebih tagas lagi penerapkan peraturan dan pemilahan lebih intens lagi kedepannya untuk sampah organik dan anorganik agar dapat mengurangi dampak kedepannya. (16 Juli 2019)

\section{Faktor yang Mempengaruhi Keberhasilan}

1. Kondisi Lingkungan

Lingkungan sangat mempengaruhi implementasi kebijakan, yang dimaksud lingkungan ini mencakup lingkungan sosio cultural serta keterlibatan penerima program

Masyarakat di Kota Batam secara umum hanya mengenal tempat sampah 1 jenis. Rata-rata ada didepan rumah. Ketidaktahuan masyarakat tentang peraturan dan manfaat pemiliahan sampah ini akhirnya semua sampah di buang menjadi satu kesatuan. Akhirnya pola pembuangan sampah ini menjadi budaya yang dilakukan setiap masyarakat di Kota Batam. Penegakan peraturan juga masih lemah diterapkan pemerintah, akhirnya peraturan tidak dipatuhi masyarakat. Bermuara dari kesadaran masyarakat yang rendah ini akhirnya pengurangan sampah di Kota Batam tidak dapat secara massif dikurangi. 
2. Hubungan antar organisasi

Dalam banyak program, implementasi sebuah program perlu dukungan dan koordinasi dengan instansi lain. Untuk itu diperlukan koordinasi dan kerjasama antar instansi bagi keberhasilan suatu program.

Dewi Mariana (36) Unit Bank Sampah Allium, Kelurahan Sei Langkai, Kecamatan Sagulung menyatakan semua unit Bank Sampah di Kota Batam rutin melakuakan koordinasi melalui Grup Pesan Instan seperti Whatsapp, selain itu setiap satu bulan sekali mereka juga ada jadwal koordinasi.

"Untuk koordinasi kami memiliki grup Whatsapp Masyarakat Peduli Sampah yang dibentuk oleh DLH Kota Batam, jadi kami bisa bertanya dan sharing apa saja disana kapan saja. Untuk ketemu tatap muka langsung juga satu bulan sekali saat pengangkutan sampah" (2019)

Untuk sosialisasi ke warga kami lakukan secara berlahan pada forum-forum warga. Awalnya susah sekali kami mencari nasabah Bank Sampah waktu itu awalanya dari 13 orang, karena sedikit tersebut namun berlahan sekarang Nasabah Bank Sampah kami berjumlah 175, bahkan kalo ada dari tempat lain yang ingin mengirim tempat kami, kami terima.

Dalam implementasinya ada juga sinergi antara Dinas Lingkungan Hidup, Unit Bank Sampah, TPS 3R, dan Dunia Usaha melakukan sinergi. Untuk bantuan peralatan dan gedung tergadang DLH Kota Batam tidak memiliki anggaran untuk membuat atau megadakan. Namun DLH Kota Batam berusaha untuk menjalin sinergi dengan Dunia Usaha dengan menjadi perantara CSR Dunia Usaha kepada Unit Bank Sampah di Kota Batam.

3. Sumberdaya

Implementasi kebijakan perlu didukung sumberdaya baik sumberdaya manusia (human resources) maupun sumberdaya non-manusia (non human resources).

a. Dinas Lingkungan Hidup Kota Batam

Sumberdaya manusia untuk bagian pengurangan Sampah sudah mencukupi menurut Ibu Rida, mereka mempunyai 2 staff dan 15 tenaga Pengangkut 3R. untuk sumber daya non manusia DLH memiliki 1 Lori, 1 Pick Up, dan 2 Becak Motor. Pick Up inilah yang dipakai untuk menjemput sampah anorganik yang bernilai ekonomis ke pabrik. Namun yang masih kurang adalah Gudang penampung di Telaga Punggur yang dibuat dengan bahan yang tidak tahan lama. 


\section{b. TPS 3R}

Di TPS 3R Tiban Lama sudah memiliki semua alat yang dibutuhkan untuk melakukan pengurangan sampah. Namun memang untuk pengurus sampai saat ini tidak ada alokasi insentif. Untuk peralatan seperti sarung tangan dan masker juga TPS 3R ini masih belum mengunakan.

c. Unit Bank Sampah

Di Unit Bank Sampah biasanya pengurus terdiri dari 3 orang. Ketua, Sekretaris dan Bendahara. Sumber daya mereka biasanya mempunyai Nasaba Bank Sampah untuk memilah sendiri sampah dirumahnya. Kendala yang terjadi di unit Bank Sampah terkadang mereka tidak mempunyai tempat khusus. Ada juga alat timbang dan mesin pengolahan sampah. Di Unit Bank Sampah juga mereka tidak mempunyai masker dan sarung tangan dalam aktivitasnya.

4. Karakteristik dan kemampuan agen pelaksana

Karakteristik dan kemampuan agen pelaksana adalah mencakup struktur birokrasi, norma-norma, dan pola-pola hubungan yang terjadi dalam birokrasi, yang semuanya itu akan mempengaruhi implementasi suatu program

Pada implementasi program pengurangan sampah di Kota Batam mempunyai beberapa agen pelaksana yakni Dinas Lingkungan Hidup Kota Batam bagian Pengurangan Sampah, Tempat Pengelolaan Sampah 3R, Unit Bank Sampah, Nasabah Bank Sampah, Dunia Usaha.

a. Dinas Lingkungan Hidup Kota Batam

Tanggung jawab kebersihan di Kota Batam sepenuhnya telah dilakukan oleh DLH Kota Batam termasuk melakukan pengurangan sampah. Pada bagian pengurangan sampah mempunyai kapasitas yang baik dalam upaya pengurangan sampah seperti telah membentuk 203 Bank Sampah di Kota Batam, melakukan pelatihan, menjaring Corporate Sosial Responsibility (CSR) dari Dunia Usaha untuk unit Bank Sampah. Namun dengan keterbatasan anggota dan anggaran bagian ini belum mampu optimal dalam hal pengurangan sampah. Hal ini terlihat dari jumlah pengurangan sampah dari timbulan sampah. Hubungan dengan Unit Bank Sampah sebatas koordinasi karena sifatnya swakelola dan tidak ada insentif dari DLH. Jadi DLH tidak dapat memberikan sangksi tegas jika unit Bank Sampah tidak aktif.

b. Tempat Pengolahan Sampah 3R 
Tempat Pengelolaan Sampah 3R ini dikelola oleh masyarakat secara swakelola. Di Kota Batam hanya terdapat 2 TPS 3R, namun hanya satu yang masih aktif kegiatannya.

c. Unit Bank Sampah

Unit Bank Sampah juga dibentuk oleh DLH Kota Batam dengan garis koordinasi langsung. Unit Bank Sampah dikelola oleh masyarakat secara swakelola. Tidak ada insentif untuk pengelola unit Bank Sampah, mereka mendapatkan uang operasional dari penjualan olahan sampah organik dan anorganik.

d. Nasabah Bank Sampah/Masyarakat

Nasabah Bank Sampah merupakan warga binaan unit Bank Sampah. Nasabah memilah jenis sampah yang bernilai ekonomis (anorganik) untuk dikumpulkan kepada Unit Bank Sampah setiap satu bulan sekali sesuai jadwal. Pengurangan sampah yang baik dan bisa massif jumlah pengurangan sampah adalah pemilahan sejak dini pada masyarakat di rumah tangga. Namun tidak semua masyarakat merupakan anggota nasabah Bank Sampah. Masih banyak masyarakat yang belum sadar dan peduli pentingnya memisahkan sampah. Dikarenakan belum menyeluruhnya gerakan pemilahan sampah dari rumah tangga, pengurangan sampah di Kota Batam masih berjumlah sangat sedikit.

e. Dunia Usaha

Dunia usaha dengan koordinasi yang baik dengan pihak pemerintah mampu memberikan bantuan CSR dengan tepat sasaran. CSR tersebut diberikan kepada unit Bank Sampah seperti bantuan gedung, Becak, bantuan alat. Secara umum sinergi antar Pemerintah (DLH Kota Batam), Dunia Usaha, dan Unit Bank Sampah sudah baik dalam melaksanakan program pengurangan sampah.

\section{KESIMPULAN}

Pengurangan sampah di Kota Batam masih harus ditingkatkan lagi kinerjanya terutama dengan menaikan jumlah Unit Pengelola Bank Sampah dan TPS3R di setiap kecamatannya. Karena gap pengurangan sampah dan timbulan sampah yang dihasilkan masih sangat kecil yakni tidak sampai $1 \%$. Berikut rangkuman kesimpulan dengan mengunakan indikator: 
1. Indikator Masukan Kebijakan

a. Belum ada Peraturan turunan untuk Peraturan Presiden No 97 Tahun 2017 tentang Kebijakan dan Strategi Nasional Pengelolaan Sampah Rumah Tangga dan Sampah Sejenis Sampah Rumah Tangga;

b. Organisasi Pelaksana yakni Unit Bank Sampah dan TPS3R jumlahnya masih sedikit;

c. Sumberdaya, jumpah mobil angkutan perluh ditambah

2. Indikator Keluaran Kebijakan

a. Akses, akses pemilahan sampah di sumber sampah masih mengunakan 1 jenis tempat sampah. Pemilahan masih mengandalkan Bank Sampah;

b. Frekuensi, Petugas pengangkut sampah ke Bank Sampah sudah sesuai dengan SOP namun karena mobil pick up jumlahnya terbatas pengangkutan dibuatkan penjadwalan dan dengan tonase yang sudah ditentukan;

c. Cakupan, Cakupan pengurangan sampah sudah di lakukan di 12 kecamatan namun jumlahnya masih kurang;

d. Bias, masih belum tersedianya fasilitas dari hulu, sosialiasi masih kurang, dan peraturan turunan di tingkat daerah yang belum ada juga menjadi kendala implementasi pengurangan sampah ini.

e. Ketepatan Layanan, pelayanan pengurangan sampah dirasa sangat tepat untuk dilaksanakan dikarena sangat vital perannya untuk masyarakat.

\section{DAFTAR PUSTAKA}

Ekawati, Sulistya. (2016). Mengkritisi Kebijakan Penanganan Kantong Plastik di Indonesia. Pusat Penelitian dan Pengembangan Sosial, Ekonomi, Kebijakan dan Perubahan Iklim: Vol 10 (6).

Solihin, Muhammad dan Parlindungan, Ronald. (2018). Implementasi Program Pengangkutan Sampah di Kota Batam Tahun 2017. Trias Politika. Vol 2 (2): 81-97.

Moleong, L.J. (2007). Metodologi Penelitian Kualitatif. Bandung: PT. Remaja Rosdakarya.

Sugiyono. (2011). Metode Penelitian Kuantitatif Kualitatif dan $R \& D$. Bandung: Alfabeta.

Purwanto, Erwan Agus dan Sulistyastuti, Dyah Ratih. (2012). Implemetasi Kebijakan Publik, Konsep, dan Aplikasinya di Indonesia. Yogyakarta: Gava Media

Nawawi, Hadari. (1992). Metode Penelitian Bidang Sosial. Yogyakarta: Press. 